\title{
Comparing the Use of Subgaleal and Subdural Drain in Non- acute Subdural Hematomas: Does the Hematoma Age Affect the Results?
}

\author{
Akut OImayan Subdural Hematomlarda Subgaleal ve Subdural Diren Kullanımının \\ KarşılaşııııIması: Kanama Yaşı Sonuçları Etkiler mi?
}

\author{
(D) Kutsal Devrim SEÇiNTi \\ Kahramanmaraş Sütçü Imam University Faculty of Medicine, Department of Neurosurgery, Kahramanmaraş, Turkey
}

\begin{abstract}
Aim: Surgical treatment of non-acute subdural hematomas is to place a closed drainage system in the subdural area following burr-hole trepanation, but it has tendency to drain related complications. Subgaleal drain is also suggested as an alternative, but there is no consensus yet. The aim of this study is to examine the effect of hematoma age and drain insertion style on surgical outcomes.

Materials and Methods: The data of 79 patients were retrospectively analyzed. The patients were divided into two groups as "subdural drain" and "subgaleal drain". Each group was further subgrouped as "chronic hematoma" and "subacute hematoma". They were compared in terms of the capacity of draining the hematoma and complications such as pneumocephalus, recurrence and others. The effect of hematoma age on results was examined.

Results: It was determined that hematoma could be evacuated more effectively in the subgaleal drain group $(p=0.045)$. It was found that in subacute hematomas, subgaleal drain resulted in more recurrence, but prevented drain-related complications. Subgaleal drain was found to be acceptable for chronic subdural hematomas.
\end{abstract}

Conclusion: The use of subgaleal drain may be an option to avoid drain-related complications. However, if the hematoma is subacute, the rate of recurrence increases.

Keywords: Subdural, hematoma, drain, subgaleal, recurrence

ÖZ

Amaç: Kronik ve subakut subdural hematomların kabul görmüş cerrahi tedavisi burr-hole trepanasyonu takiben subdural alana kapalı diren sistemi yerleştirmektir. Direne bağlı komplikasyonlara açık olan bu yönteme alternatif olarak direnin subgaleal alana yerleştirilebileceği de önerilmektedir, ancak henüz bu konuda görüş birliği sağlanamamıştır. Bu çalışmada amaç, kronik veya subakut subdural hematomun cerrahi tedavisinde kanamanın yaşının ve direnin subgaleal alana veya subdural alana yerleştirilmesinin cerrahi başarı üzerindeki etkisini incelemektir.

Gereç ve Yöntem: Kriterlere uyan ve takiplerine eksiksiz ulaşılabilen 79 hastanın verileri geriye dönük incelendi. Hastalar, kullanılan cerrahi yönteme göre "subdural diren grubu" ve subgaleal diren grubu" olarak iki gruba ayrıldı. Her bir grup ayrıca kendi içinde "kronik kanaması olanlar" ve "subakut kanaması olanlar" olarak iki alt gruba daha ayrıldı. Gruplar, uygulanan yöntemin kanamayı boşaltabilme kapasitesi, pnömosefali, rekürrens ve diğer komplikasyonlar açısından kıyaslandı. Kanamanın yaşının sonuçlara etkisi incelendi.

Bulgular: Subgaleal diren grubunda kanamanın daha etkili şekilde boşaltılabildiği belirlendi ( $p=0,045)$. Subakut kanamada subgaleal direnin daha fazla rekürrens ile sonuçlandığı ancak direne bağlı komplikasyonları önlediği fark edildi. Kronik kanaması olan hastalarda ise subgaleal diren yerleştirilmesinin kabul edilebilir olduğu saptandı.

Address for Correspondence: Kutsal Devrim SEÇiNTi MD, Sütçü İmam University Faculty of Medicine, Department of Neurosurgery, Kahramanmaraş, Turkey Phone: +90 5056057692 E-mail: devrimsecinti@yahoo.com ORCID ID: orcid.org/0000-0003-4345-0805

Received: 13.12.2020 Accepted: 13.02.2021 
Sonuç: Direne bağlı komplikasyonlardan kaçınabilmek için subgaleal diren kullanılması seçenek olabilir. Ancak subakut hematom varlığında rekürrens oranı artmaktadır.

Anahtar Kelimeler: Subdural, hematom, diren, subgaleal, rekürrens

\section{INTRODUCTION}

Symptomatic subdural hematomas are very common in neurosurgery practice and are predominantly detected in elderly patients. Both the increase in life expectancy in developed countries and the more accessible and more frequent use of antiplatelet and antiaggregant drugs cause an increase in chronic subdural hematoma cases ${ }^{1,2}$. Surgery is generally recommended when subdural hematoma becomes symptomatic. The recommended treatment in chronic or subacute subdural hematoma surgery is evacuation of the hematoma with a burr-hole craniostomy and closed drainage system $^{3}$. Surgical complications are generally stated as infection, acute hematoma, seizure, symptomatic hygroma, and symptomatic pneumocephalus ${ }^{4}$. It is also known that this method, which has proven to be quite effective, can cause epileptic seizure due to cortex irritation or motor deficit and parenchymal hematoma due to cortex injury ${ }^{4,5}$.

In recent years, the method in which the drain is placed in the subgaleal (subperiosteal) area instead of the subdural area following burr-hole opening has attracted attention ${ }^{5-7}$. Because placing the drain in the subgaleal area seems to protect the physician and the patient from these complications $s^{6,7}$. It is claimed that it is equal to or superior to subdural drain placement in terms of both complications and capacity to drain hematoma ${ }^{5-7}$. Although there are studies focused on this subject in the literature, the effect of the hematoma age on the results has not been examined before.

In our clinic, mainly subgaleal drain application has been performed since 2018 in order to avoid complications related to the drain. Burr-hole diameters are kept the same as those in the classical method and blunt-ended soft silicone drains are used as standard. Regardless of the number of burr-holes, a single drain is always used for the same hemisphere. In patients undergoing two burr-hole craniostomies on the same side, a single drain is placed under the skin from back to front, crossing both burr-hole openings. Our clinical observations are that our surgical success has not changed, but our complication rates have decreased. The presented study was carried out with the aim of confirming these observations.

\section{MATERIALS AND METHODS}

\section{Patient Selection and Determination of Groups}

Following the approval document obtained from the Local Ethics Committee of Kahramanmaraş Sütçü İmam University (decision no: 2020/17-04), 138 patients who underwent surgical drainage with the diagnosis of subdural hematoma in our clinic between October 2017 and June 2020 in accordance with the Principles of the Declaration of Helsinki were retrospectively reviewed. Patients with acute subdural hematoma, patients who underwent craniotomy despite having subacute or chronic subdural hematoma, and pediatric patients with subdural hygroma or subdural hematoma due to shunt ovarian drainage were not included in the study. In order not to cause confusion in the discussion and interpretation of the data, patients who underwent bilateral surgery were also excluded from the study. Seventy-nine patients who met the criteria and whose data were fully accessible were included in the study. It was determined that 33 patients were treated with subdural drain (Figure 1) and 46 patients were treated with subgaleal drain (Figure 2). The patients were further divided into two more subgroups according to the stage of their hematoma as "those with subacute hematoma" and "those with chronic hematoma". Thus, it was aimed to determine whether the hematoma age affects the surgical success or not. Demographic data of the patients are summarized in Table 1.
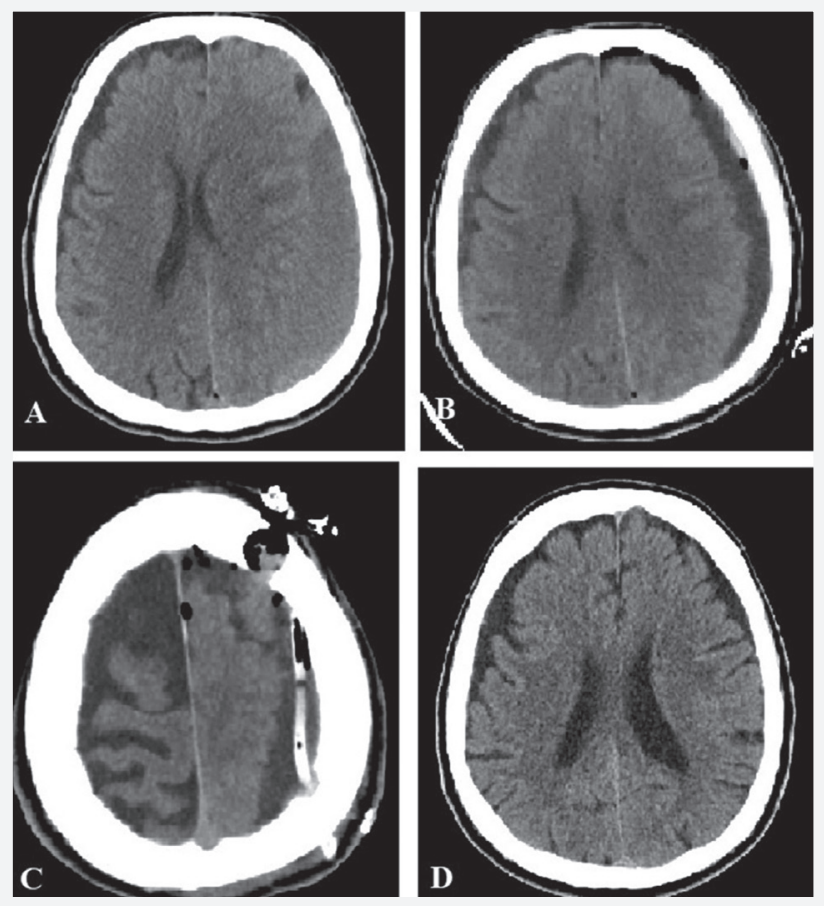

Figure 1. Cranial tomography images of a patient treated with a subdural drain. A) Preoperative hematoma status, $B$ and $C$ ) Images obtained on the $3^{\text {rd }}$ postoperative day [C) appearance of the drain in the subdural area], and D) Cranial tomography image at the $1^{\text {st }}$ month postoperatively 

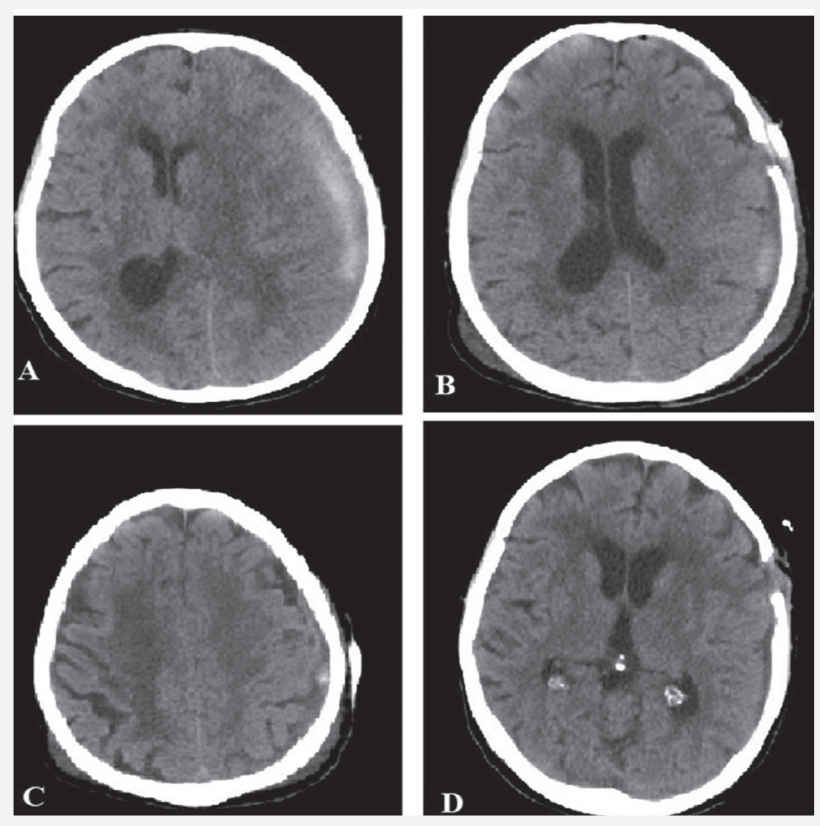

Figure 2. Cranial tomography images of a patient treated with subgaleal drain. A) Preoperative hematoma status, $B$ and C) Images obtained on the $3^{\text {rd }}$ postoperative day (position of the drain in the subgaleal area), and D) Cranial tomography image at the $1^{\text {st }}$ month postoperatively

\section{Measurements}

The blood volumes at the time of admission, the blood volumes on the third postoperative day and the first month postoperative blood volumes of all patients were calculated from tomography images. The surgical results of the patients were evaluated in terms of insufficient drainage, recurrence, pneumocephalus, and the capacity of the techniques to drain blood. In addition, the effects of patient age and gender on surgical outcomes were also examined. X.Y.Z/2 formula, which is one of the accepted classical methods, was used in the calculation of blood volume and pneumocephalus volume ${ }^{8}$.

\section{Statistical Analysis}

All data were analyzed with the Statistical Package for the Social Sciences v21 Software program. It was determined that in the normality test (Shapiro-Wilk test), the quantitative data [age, preoperative blood volume (V1), postoperative third day (V2) and postoperative first month (V3) blood volumes and pneumocephaly volumes and their percentage values] were not normally distributed and descriptive statistics were given as "mean, median, standard deviation, lowest and highest". Mann-Whitney $U$ test, which is one of the nonparametric tests, was used in the analysis of quantitative data, and Fisher's Exact test was used in the analysis of qualitative data. Statistical significance value was accepted as $p<0.05$.

\begin{tabular}{|c|c|c|}
\hline & $\begin{array}{l}\text { Subdural } \\
\text { drain }\end{array}$ & $\begin{array}{l}\text { Subgaleal } \\
\text { drain }\end{array}$ \\
\hline Number of patients & 33 & 46 \\
\hline Age [mean (min-max)] & $71.6(35-92)$ & $68.95(37-90)$ \\
\hline Female (n) & 7 & 8 \\
\hline Male (n) & 26 & 38 \\
\hline Chronic hematoma (n) & 18 & 25 \\
\hline Subacute hematoma (n) & 15 & 21 \\
\hline $\begin{array}{l}\text { Preoperative blood volume }\left(\mathrm{cm}^{3}\right) \\
\text { (V1) (mean) }\end{array}$ & 205.7 & 197.8 \\
\hline $\begin{array}{l}\text { Postoperative third day blood } \\
\text { volume }\left(\mathrm{cm}^{3}\right)(\mathrm{V} 2) \text { (mean) }\end{array}$ & 83.7 & 75.9 \\
\hline $\begin{array}{l}\text { First month postoperative blood } \\
\text { volume }\left(\mathrm{cm}^{3}\right)(\mathrm{V} 3) \text { (mean) }\end{array}$ & 44.8 & 28,9 \\
\hline $\begin{array}{l}\text { Number and percentage of primary } \\
\text { surgical complications }\end{array}$ & $6^{(1)}(18 \%)$ & $1^{(I I)}(2 \%)$ \\
\hline $\begin{array}{l}\text { Number and percentage of } \\
\text { secondary surgical complications }\end{array}$ & $2^{(I I I)}(6 \%)$ & $5^{(\mathrm{IV})}(10.9 \%)$ \\
\hline Recurrence & $0(0 \%)$ & $4(8.7 \%)$ \\
\hline $\begin{array}{l}\text { Pneumocephalus volume }\left(\mathrm{cm}^{3}\right) \\
\text { (mean) }\end{array}$ & 17.1 & 14.8 \\
\hline \multicolumn{3}{|c|}{$\begin{array}{l}\text { The table summarizes the combined results of the two surgical methods and the } \\
\text { demographic data of the patients. The data of the table was created without } \\
\text { considering the hematoma age (subacute/chronic) of the patients. }\end{array}$} \\
\hline \multicolumn{3}{|c|}{$\begin{array}{l}\text { V1: patient's preoperative blood volume. V2: patient's blood volume on the third } \\
\text { postoperative day. V3: patient's blood volume in the first postoperative month). [(I): } \\
\text { drain-related seizure in one patient, cortical injury in three patients, insufficient } \\
\text { drainage in two patients. }{ }^{(I I)} \text { : insufficient drainage in one patient. }{ }^{(I I)} \text { : death from } \\
\text { pneumonia in two patients. }{ }^{(\mathrm{M})} \text { : death from pneumonia in three patients, hypertensive } \\
\text { parenchymal hematoma in two patients (no surgery)]. min: Minimum, max: } \\
\text { Maximum }\end{array}$} \\
\hline
\end{tabular}

\section{RESULTS}

79\% of the patients were male patients. All patients with insufficient drainage and recurrence were male. This complication was never seen in women. However, statistical analysis was not carried out, as this situation may also be due to the size of the numerical difference between the genders.

It was observed that the blood volumes of female patients at the time of admission were statistically significantly lower compared to male patients. While the median value of blood volumes was $155 \mathrm{~cm}^{3}$ in women at the time of admission, this rate was $195 \mathrm{~cm}^{3}$ in men $(p=0.018)$. However, there was no relationship between the volume of blood that could be drained and gender. Between men and women, early postoperative blood volume (V2) was found as $p=0.125$ and postoperative first month blood volume (V3) was found as $p=0.604$.

It was observed that the mean value of blood volumes at the time of admission of patients with subacute hematoma was higher than those presenting with chronic hematoma. However, it was not statistically significant $(p=0.779)$. It was determined that the blood volume (V2) was slightly higher in the early postoperative period in subacute hemorrhage, but it was not statistically significant $(p=0.533)$ (Table 2$)$. 
Table 2. The effect of hematoma age and drain location on the ability of hematoma to be drained

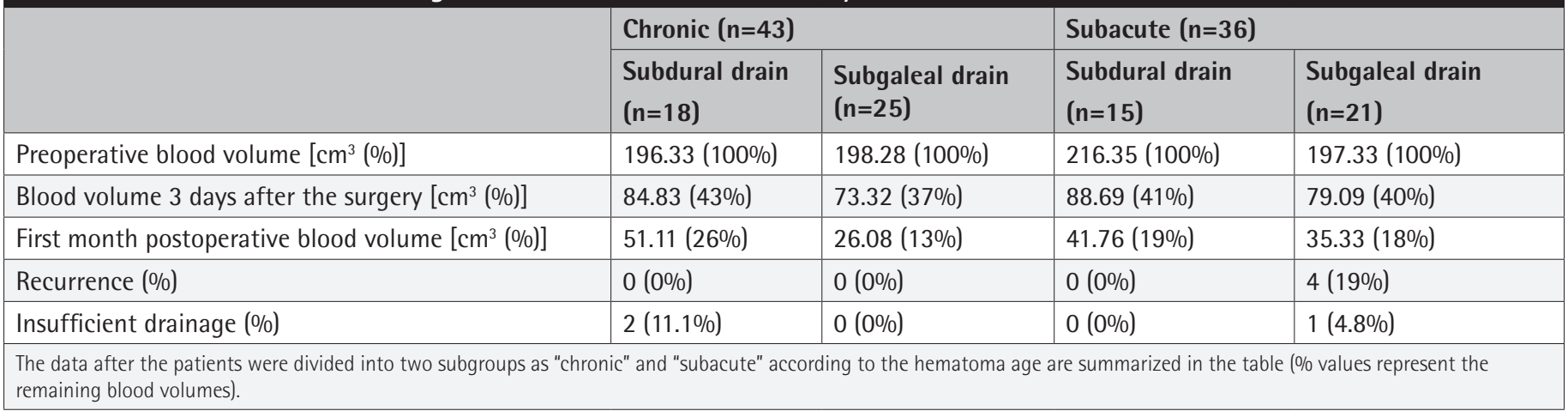

When both techniques were compared in terms of primary surgical complications, it was determined that inadequate drainage was observed in two (6.1\%) of 33 patients in the subdural drain group and in one (2.2\%) of 46 patients in the subgaleal drain group. There was no statistical difference between the groups $(p=0.568)$. No other primary surgical complications such as acute subdural hematoma, acute epidural hematoma, or surgical site infection were encountered in either group (Table 1). This review was performed without including recurrence rates. When recurrences were added to the primary surgical complication list, it was determined that there was no statistical difference between the groups $(p=0.512)$. When recurrence was evaluated under a separate heading, the recurrence rate was $0 \%(0 / 33)$ in the subdural drain group and $8.7 \%(4 / 46)$ in the subgaleal drain group. However, there was no statistical difference (Fisher's Exact test, $\mathrm{p}=0.136$ ).

In terms of pneumocephalus rates, the mean air volume was found to be $17.1 \mathrm{~cm}^{3}$ in the subdural drain group and $14.8 \mathrm{~cm}^{3}$ in the subgaleal drain group (Table 1). Although it was seen that the subgaleal drain group was somewhat more advantageous in this regard, no statistical difference was found between the groups ( $p=828)$.

On the other hand, it was determined that all recurrences in the subgaleal drain group developed in patients with subacute hematoma (4/21) and none in the same group with chronic hematoma $(0 / 25)$ developed recurrences. When analyzed in terms of recurrence rates, it was observed that both techniques were not superior to each other in patients with chronic hematoma, but the recurrence rate was higher in subgaleal drains placed in patients with subacute hematoma (Table 2). In the subdural drain group, the complication rate due to placement of the drain in the subdural space was $12 \%(4 / 33)$. There was no statistically significant difference between the genders in terms of primary surgical complications (Fisher's Exact test $p=0.429$ ). The drainage capacity of the drain site, regardless of the type of hematoma, is summarized in Table 3 for all groups.
When both techniques were compared in terms of patients only with subacute hematoma, no difference was found between the blood drainage capacities of both techniques $(p=0.196)$. Again, when both techniques were examined only in terms of patients with chronic hematoma, it was determined that subgaleal drain was statistically more successful at the end of the first month $(p=0.042)$. In addition, when chronic and subacute hematomas were evaluated together, it was determined that the rate of evacuation of the subgaleal drain at the end of the first month was statistically better ( $p=0.045)$. The combined effects of the type of hematoma (hematoma age) and the drain site on the rate of blood discharge are summarized in Table 4.

\section{DISCUSSION}

There is no consensus on the use of drains and drain localization in surgeries where symptomatic chronic and subacute subdural hematomas are drained by burr-hole. In a comprehensive study on this subject, it is stated that the choice of surgeons varies among geographical regions. For example, it is stated that $80 \%$ of surgeons in Africa, 83.7\% in Europe and 100\% in America use drains, while 50\% of Asian surgeons do not use drains ${ }^{9}$. There are differences not only between regions but also between countries. According to studies, only $11 \%$ of surgeons in England state that they always use drains ${ }^{10}$, while this rate rises to $80.6 \%$ in Canada". The rate of drain use is 29.5\% in India and $42.9 \%$ in Nigeria ${ }^{12,13}$.

It seems that it is not absolutely necessary to use a drain in the surgical treatment of chronic or subacute subdural hematomas. However, the presence of a drain may suggest to the physician that hematoma will be drained more effectively. Twist drill craniostomy technique probably arose from the need to avoid complications related to the drain, on the one hand, and the sense of confidence given by the presence of the drain, on the other hand. Because, as is known, a drain is used in this technique, but unlike the classical method, this drain is not advanced in the subdural area, but is fixed just below the dura. In this way, it is aimed to avoid complications related to the 
Table 3. Drainage capacity of the drain site independent of hematoma age

\begin{tabular}{|c|c|c|c|c|c|c|c|}
\hline \multicolumn{2}{|l|}{ GROUP } & Age & V1 & V2 & V3 & Remaining V2\% & Remaining V3\% \\
\hline \multirow{6}{*}{$\begin{array}{l}\text { Subdural drain } \\
\text { (chronic+subacute) }\end{array}$} & $\mathrm{N}$ & 33 & 33 & 32 & 31 & 32 & 31 \\
\hline & Mean & 71,64 & 205,6667 & 83,7500 & 45,5484 & 42,0395 & 21,6665 \\
\hline & Median & 74,00 & 190,0000 & 75,0000 & 41,0000 & 39,0420 & 14,3860 \\
\hline & SD & 13,788 & 76,56438 & 56,90513 & 56,04929 & 25,02327 & 24,84841 \\
\hline & Minimum & 35 & 91,00 & 0,00 & 0,00 & 0,00 & 0,00 \\
\hline & Maximum & 92 & 369,00 & 267,00 & 260,00 & 106,80 & 104,00 \\
\hline \multirow{6}{*}{$\begin{array}{l}\text { Subgaleal drain } \\
\text { (chronic+subacute) }\end{array}$} & $\mathrm{N}$ & 46 & 46 & 46 & 43 & 46 & 43 \\
\hline & Mean & 68,96 & 197,8478 & 75,9565 & 29,9535 & 37,1462 & 14,0767 \\
\hline & Median & 71,00 & 188,5000 & 67,0000 & 11,0000 & 37,9130 & 4,2683 \\
\hline & SD & 14,525 & 82,38904 & 56,51979 & 51,04478 & 21,04019 & 23,19783 \\
\hline & Minimum & 37 & 70,00 & 0,00 & 0,00 & 0,00 & 0,00 \\
\hline & Maximum & 90 & 442,00 & 237,00 & 225,00 & 84,75 & 94,74 \\
\hline \multirow{6}{*}{ Total } & $\mathrm{N}$ & 79 & 79 & 78 & 74 & 78 & 74 \\
\hline & Mean & 70,08 & 201,1139 & 79,1538 & 36,4865 & 39,1537 & 17,2562 \\
\hline & Median & 72,00 & 190,0000 & 73,5000 & 16,0000 & 38,5890 & 9,4381 \\
\hline & SD & 14,194 & 79,59996 & 56,44008 & 53,38674 & 22,73049 & 24,03275 \\
\hline & Minimum & 35 & 70,00 & 0,00 & 0,00 & 0,00 & 0,00 \\
\hline & Maximum & 92 & 442,00 & 267,00 & 260,00 & 106,80 & 104,00 \\
\hline \multicolumn{8}{|c|}{$\begin{array}{l}\text { V1, V2, and V3: represent the preoperative blood volumes, postoperative third day, postoperative first month, respectively. The common descriptive data of patients in whom the } \\
\text { drain was placed in the subdural space and in the subgaleal space are summarized in the table. Since the data are not normally distributed, it is recommended to consider the } \\
\text { median values instead of the mean values when interpreting the table. As can be seen in the last column, the residual blood volume (remaining V3\%) at the end of the first month } \\
\text { was } 14.38 \% \text { of the preoperative blood volume in the subdural drain group, while the same rate was } 4.26 \% \text { in the subgaleal drain group. SD: Standard deviation }\end{array}$} \\
\hline
\end{tabular}

drain ${ }^{14}$. This technique did not reach its intended prevalence as it required unique equipment/kits, but it probably pioneered the application of subdural drains by showing that even a surface drain is effective.

The data of another study confirms all these concerns about the use of drain. In the related study, it is stated that the surgeon's experience and the preference to use a drain are inversely proportional, and this is simply explained as "to abstain from using a drain after a previous drain-related complication"15. The reason for starting subgaleal drain application in our clinic is that similar complications have been experienced.

When it is decided to use a drain, there is still no consensus in the literature on whether it is more appropriate to place it in the subdural or subperiosteal (subgaleal) area. According to a study by Soleman et al. ${ }^{9}$, the use of subdural drains is still $50 \%$ among surgeons, while the rate of use of subgalel drains is $27 \%$. They attribute the reason for this situation to the low evidence value of the publications on the use of subgaleal drains and the fact that it is a partially new approach. Again, according to the same study, it is stated that if a drain is to be used, experienced surgeons prefer subdural drain, while new generation (less experienced) surgeons prefer subgaleal drain. This situation is briefly explained as "experienced surgeons have difficulty in giving up their old habits, but new surgeons adapt more easily to new methods"9. In short, the experienced surgeon chooses not to use a drain if possible ${ }^{15}$, but when he decides to use a drain, he cannot give up his old habit and uses a subdural drain?.

In another study on the use of subgaleal drains, it was reported that the complication rates, including pneumocephalus, were higher in the subdural drain group compared to the subgaleal drain group ${ }^{16}$. In another study, pneumocephalus was not evaluated, but it was reported that the subgaleal drain technique was more advantageous in terms of all other complications, including recurrence ${ }^{17}$. In both studies, it was stated that there was no statistical difference between the techniques and the hematoma drainage capacities have been reported to be comparable to each other ${ }^{16,17}$. Soleman et al. ${ }^{18}$, on the other hand, stated that the use of subgaleal drains reduced the rates of recurrence and infection, but the difference was again not statistically significan.

In the present study, it was determined that there was no difference between the groups in terms of insufficient drainage and other "drain unrelated" primary surgical complications. In terms of recurrence numbers, recurrence was observed in 4 patients in the subgaleal drain group, but not in any patient in the subdural drain group. The findings are also consistent with 
Table 4. Joint effect of hematoma type and drain site on blood drainage rate

\begin{tabular}{|c|c|c|c|c|c|c|}
\hline \multicolumn{2}{|l|}{ Group } & \multirow{2}{*}{$\begin{array}{l}\text { V1 } \\
18 \\
\end{array}$} & \multirow{2}{*}{$\begin{array}{l}\text { V2 } \\
18\end{array}$} & \multirow{2}{*}{$\begin{array}{l}\text { V3 } \\
17 \\
\end{array}$} & \multirow{2}{*}{$\begin{array}{l}\text { Remaining V2\% } \\
18\end{array}$} & \multirow{2}{*}{$\begin{array}{l}\text { Remaining V3\% } \\
17\end{array}$} \\
\hline \multirow{6}{*}{$\begin{array}{l}\text { Subdural drain (chronic } \\
\text { hematoma) }\end{array}$} & $\mathrm{N}$ & & & & & \\
\hline & Mean & 196,3333 & 84,8333 & 51,1176 & 41,9276 & 23,9828 \\
\hline & Median & 192,5000 & 75,0000 & 41,0000 & 36,7160 & 17,1717 \\
\hline & SD & 62,89581 & 63,86313 & 68,53091 & 28,19363 & 30,28547 \\
\hline & Minimum & 120,00 & 0,00 & 0,00 & 0,00 & 0,00 \\
\hline & Maximum & 358,00 & 267,00 & 260,00 & 106,80 & 104,00 \\
\hline \multirow{6}{*}{$\begin{array}{l}\text { Subgaleal drain (chronic } \\
\text { hematoma) }\end{array}$} & $\mathrm{N}$ & 25 & 25 & 25 & 25 & 25 \\
\hline & Mean & 198,2800 & 73,3200 & 26,0800 & 34,9974 & 9,9507 \\
\hline & Median & 185,0000 & 47,0000 & ,0000 & 33,0357 & 0,0000 \\
\hline & SD & 85,03750 & 59,70254 & 47,82339 & 20,26949 & 13,34893 \\
\hline & Minimum & 91,00 & 0,00 & 0,00 & 0,00 & 0,00 \\
\hline & Maximum & 442,00 & 237,00 & 225,00 & 76,76 & 50,90 \\
\hline \multirow{6}{*}{$\begin{array}{l}\text { Subdural drain (subacute } \\
\text { hematoma) }\end{array}$} & $\mathrm{N}$ & 15 & 14 & 14 & 14 & 14 \\
\hline & Mean & 216,8667 & 82,3571 & 38,7857 & 42,1833 & 18,8540 \\
\hline & Median & 184,0000 & 75,0000 & 34,0000 & 43,3879 & 13,5042 \\
\hline & SD & 91,37354 & 48,83348 & 37,14251 & 21,29933 & 16,74700 \\
\hline & Minimum & 91,00 & 0,00 & 0,00 & 0,00 & 0,00 \\
\hline & Maximum & 369,00 & 181,00 & 140,00 & 82,42 & 47,18 \\
\hline \multirow{6}{*}{$\begin{array}{l}\text { Subgaleal drain (subacute } \\
\text { hematoma) }\end{array}$} & $\mathrm{N}$ & 21 & 21 & 18 & 21 & 18 \\
\hline & Mean & 197,3333 & 79,0952 & 35,3333 & 39,7044 & 19,8073 \\
\hline & Median & 190,0000 & 79,0000 & 11,5000 & 38,9222 & 8,0337 \\
\hline & SD & 81,20796 & 53,77072 & 56,17619 & 22,14465 & 31,90841 \\
\hline & Minimum & 70,00 & 0,00 & 0,00 & 0,00 & 0,00 \\
\hline & Maximum & 379,00 & 190,00 & 180,00 & 84,75 & 94,74 \\
\hline $\begin{array}{l}\text { The descriptive data of the patien } \\
\text { it is recommended to use "median } \\
\text { the median value of the residual } \\
\text { group with chronic hematoma bu }\end{array}$ & $\begin{array}{l}\text { subgrouping as } \\
\text { in the evaluat } \\
\text { lume percentas } \\
\text { drain was plac }\end{array}$ & $\begin{array}{l}\text { nd subacute ac } \\
\text { table. As can b } \\
\text { ing V } 3 \% \text { ) at th } \\
\text { subdural area. }\end{array}$ & $\begin{array}{l}\text { ding to hemat } \\
\text { en from the ta } \\
d \text { of the first } r\end{array}$ & $\begin{array}{l}\text { age are summ } \\
n \text { the case of } \\
h \text { was } 0.00 \% \text {, }\end{array}$ & $\begin{array}{l}d \text { in the table. Since the } \\
\text { a subgaleal drain in pa } \\
\text { the same volume was }\end{array}$ & $\begin{array}{l}\text { are not normally distribut } \\
\text { with chronic hematoma, } \\
\text { red as } 17.17 \% \text { in the pati }\end{array}$ \\
\hline SD: Standard deviation & & & & & & \\
\hline
\end{tabular}

the literature ${ }^{16-18}$. What is interesting is that all recurrences in the subgaleal drain group were observed in patients with subacute hematoma, but not in patients with chronic hematoma, and as far as we can determine, this is a new finding for the literature. This may be related to the viscosity change that will develop depending on the hematoma age. Subgaleal drain seems to be less effective in draining subacute hematomas, which are expected to have higher viscosity.

When all patients were evaluated together, regardless of the hematoma age, it was observed that the subgaleal drain was able to drain the hematoma more successfully $(p=0.045)$. This finding is inconsistent with the general literature. Because, although the findings in this direction are generally reached in the studies, it is stated that the results are not statistically significant ${ }^{7,16-18}$. However, it was seen that the results of both methods were not statistically different in terms of early postoperative blood volumes (V2). In other words, the change that made a statistical difference occurred in the last month when the patients had no drains. Therefore, we could not explain the reason why subgaleal drain placement is superior to the classical method. It was examined retrospectively whether the situation was related to the number of burr-holes, burr hole diameter and drain type, but it was determined that it was not related to these either. When the demographic data of the groups were compared, it was determined that both groups had similar characteristics for each parameter examined.

On the other hand, in the presented study, while there was no statistical difference between the two methods in patients with subacute hematoma, it was found that subgaleal drain was statistically more effective in patients with chronic hematoma. The reason why the findings of the study differ from the existing literature may be that hematomas were not examined separately as chronic and subacute in the mentioned studies. 


\section{Study Limitations}

The limitation of the presented study is the low number of patients. If the number of patients is increased, it is also possible that the statistical difference between the two methods can be eliminated in terms of drainage capacity of the hematoma.

\section{CONCLUSION}

In conclusion, both methods are quite similar to each other in their capacity to drain the hematoma. Subdural drain placement has the potential to cause complications related to the drain, while subgaleal drain placement increases recurrence rates (especially in patients with subacute hematoma). If the hematoma is chronic, subgaleal drain seems to be more advantageous, but this decision is still controversial in subacute hematomas. The physician should decide according to his own experience whether he should take the risk of complications related to the drain or the risk of recurrence.

\section{Ethics}

Ethics Committee Approval: The study were approved by the Kahramanmaraş Sütçü İmam University of Local Ethics Committee (decision no: 2020/17-04).

Informed Consent: Retrospective study.

Peer-review: Externally and internally peer-reviewed.

Financial Disclosure: The author declared that this study received no financial support.

\section{References}

1. Baechli $H$, Nordmann A, Bucher HC, Gratzl O. Demographics and prevalent risk factors of chronic subdural haematoma: results of a large singlecenter cohort study. Neurosurg Rev. 2004;27:263-6.

2. Chen JC, Levy ML. Causes, epidemiology, and risk factors of chronic subdural hematoma. Neurosurg Clin N Am. 2000;11:399-406.

3. Weigel $R$, Schmiedek $P$, Krauss JK. Outcome of contemporary surgery for chronic subdural haematoma: evidence based review. J Neurol Neurosurg Psychiatry. 2003;74:937-43.
4. Kravtchouk AD, Likhterman LB, Potapov AA, El-Kadi H. Postoperative complications of chronic subdural hematomas: prevention and treatment. Neurosurg Clin N Am. 2000;11:547-52.

5. Zumofen D, Regli L, Levivier M, Krayenbühl N. Chronic subdural hematomas treated by burr hole trepanation and a subperiostal drainage system. Neurosurgery. 2009;64:1116-21.

6. Gazzeri R, Galarza M, Neroni M, Canova A, Refice GM, Esposito S Continuous subgaleal suction drainage for the treatment of chronic subdural haematoma. Acta Neurochir (Wien). 2007;149:487-93.

7. Bellut D, Woernle CM, Burkhardt JK, Kockro RA, Bertalanffy $H_{\text {, }}$ Krayenbühl N. Subdural drainage versus subperiosteal drainage in burrhole trepanation for symptomatic chronic subdural hematomas. World Neurosurg. 2012;77:111-8.

8. Sucu HK, Gokmen M, Gelal F. The value of XYZ/2 technique compared with computer-assisted volumetric analysis to estimate the volume of chronic subdural hematoma. Stroke. 2005;36:998-1000.

9. Soleman J, Kamenova M, Lutz K, Guzman R, Fandino J, Mariani L. Drain Insertion in Chronic Subdural Hematoma: An International Survey of Practice. World Neurosurg. 2017;104:528-36.

10. Santarius T, Lawton R, Kirkpatrick PJ, Hutchinson PJ. The management of primary chronic subdural haematoma: a questionnaire survey of practice in the United Kingdom and the Republic of Ireland. Br J Neurosurg. 2008;22:529-34.

11. Cenic A, Bhandari M, Reddy K. Management of chronic subdural hematoma: a national survey and literature review. Can J Neurol Sci. 2005;32:501-6.

12. Santarius $T$, Kirkpatrick PJ, Kolias AG, Hutchinson PJ. Working toward rational and evidence-based treatment of chronic subdural hematoma. Clin Neurosurg. 2010;57:112-22.

13. Rabiu TB. Chronic subdural hematoma: A survey of neurosurgeons' practices in Nigeria. Surg Neurol Int. 2013;4:58.

14. Wang QF, Cheng C, You C. A New Modified Twist Drill Craniostomy Using a Novel Device to Evacuate Chronic Subdural Hematoma. Medicine (Baltimore). 2016;95:e3036.

15. Santarius T, Kirkpatrick PJ, Ganesan D, Chia HL, Jalloh I, Smielewski $P$, et al. Use of drains versus no drains after burr-hole evacuation of chronic subdural haematoma: a randomised controlled trial. Lancet. 2009;374:1067-73.

16. Ishfaq A. Outcome in Chronic Subdural Hematoma After Subdural vs. Subgaleal Drain. J Coll Physicians Surg Pak. 2017;27:419-22.

17. Chih AN, Hieng AW, Rahman NA, Abdullah JM. Subperiosteal Drainage versus Subdural Drainage in the management of Chronic Subdural Hematoma (A Comparative Study). Malays J Med Sci. 2017;24:21-30.

18. Soleman J, Lutz K, Schaedelin S, Kamenova M, Guzman R, Mariani L, et al. Subperiosteal vs Subdural Drain After Burr-Hole Drainage of Chronic Subdural Hematoma: A Randomized Clinical Trial (cSDH-Drain-Trial). Neurosurgery. 2019;85:825-34. 